\title{
短報
}

\section{ヘキソサミンを指標とした マハ夕腸管組織における粘液定量法}

安田拓, ${ }^{1}$ 木原 稔 $2 *$

(2011 年 3 月 24 日受付, 2011 年 6 月 8 日受理)

1 東海大学大学院理工学研究科環境生物科学専攻,

2 東海大学生物理工学部海洋生物科学科

Quantitative analysis of intestinal tissue mucus by hexosamine determination

TAKU YASUDA ${ }^{1}$ AND MINORU KIHARA ${ }^{2 *}$

${ }^{1}$ Graduate School of Science and Engineering Course of Environmental and Biological Sciences, Tokai University, Sapporo, Hokkaido 005-8601, ${ }^{2}$ Department of Marin Biology and Sciences, Tokai University, Sapporo, Hokkaido 005-8601, Japan

キーワード：腸組織，粘液，へキソサミン，マハタ

魚類表皮には角質化した細胞がなく, 体表面は常に環 境水々直接接していることから, 絶えず病原体侵入の危 険にさらされている。いっぽう消化管も, 食物ととも に大量の微生物や抗原が管腔内に侵入することから, 病 原菌の侵入の危険が大きい部位である。2)こういった皮 膚全体や消化管管腔内を覆う粘液は, 表面部位からの異 物の侵入を防ぐ物理的バリアーとして重要な役割を果た していると考元られて抢り, ${ }^{3)}$ 粘液の分泌促進法を研究 することは，魚病対策上重要な意義があるといえる。

組織内粘液の研究には, 主に組織化学的方法が用いら れる。しかし, 組織標本の作製には設備, 技術, 時間を 要するという難点が挙げられる。そこで簡便な組織内の 粘液の定量方法として, 粘液成分のへキソサミンを指標 とした定量方法がヒト胃組織で報告されており，4,5) その 妥当性の証明がなされている。しかし, 魚類腸の組織に 抢ける測定の妥当性の検討, 組織標本を用いた測定方法 との比較検討は行われていない。そこで本研究では, 簡 便な粘液定量方法の確立を目的に, マハ夕腸組織内粘液 を，へキソサミンを指標とした分析化学的手法で定量 し, この方法の妥当性を検討するために, 従来から行わ れている組織標本を用いた形態定量法(組織化学的手法) による粘液量との相関を確認した。ハ夕類やフグ類に は, 腸管への粘液胞子虫の寄生が知られており, ${ }^{6}$ 今後 はこれら魚種の腸管粘液分泌の研究も重要になるであろ うことをふまえ，今回供試魚にはマハ夕を用いた。

$60 \mathrm{~L}$ ガラス製循環ろ過式水槽にマハタ Epinephelus septemfasciatus（平均体重 $53 \mathrm{~g}$ ）を給餌群と絶食群に 4 尾ずつ分けて収容した。給䬣群にのみ, 2 日に 1 度, 配 合飼料（まだい育成用飼料 MZ30, 昭和産業株式会社） を 9：00 に飽食給慨した。水温を $23^{\circ} \mathrm{C}$ に調節し， 8 ： 00 20：00 の間照明した。以上の条件で 20 日間飼育 した後, 麻酔下で開腹して腸を摘出し, 肛門側から約 1 $\mathrm{cm}$ の部位の湿重量約 $0.1 \mathrm{~g}$ の組織を切り取り分析化学 的手法による粘液量を測定した。粘液量の測定は, 簡便 な粘液定量方法として報告されているNeuhaus の方 法7)をヒト生検試料の測定に応用した桶谷ら ${ }^{8)}$ の方法に 従った。すなわち, 生検材料を $4 \mathrm{~N}$ 塩酸 $0.2 \mathrm{~mL}$ 中で $100^{\circ} \mathrm{C}, 9$ 時間加水分解した。 $4 \mathrm{~N}$ 水酸化ナトリウム水溶 液で中和し, 蒸留水で $5 \mathrm{~mL}$ に定量した後, ろ紙（アド バンテック，No. 5A）で濾過した。濾液 $1 \mathrm{~mL}$ にアセ チルアセトン試薬 $\left(\mathrm{Na}_{2} \mathrm{CO}_{3} 4 \mathrm{~g}\right.$ 打よび $\mathrm{NaHCO}_{3} 1.05 \mathrm{~g}$ を蒸留水 $50 \mathrm{~mL}$ に溶解し, アセチルアセトン $1.5 \mathrm{~mL}$ を 加えたもの） $1 \mathrm{~mL}$ を加え $100^{\circ} \mathrm{C}, 20$ 分間加熱した。水 冷した後, イソアミルアルコールを $2 \mathrm{~mL}$ 加えて攪拌し, $1360 \times \mathrm{g}, 10$ 分間遠心分離した。上層のイソアミルア ルコール層 $1 \mathrm{~mL}$ をり, Ehrlich 試薬（ $p$-ジメチルア ミノベンズアルデヒド $0.8 \mathrm{~g}$ を濃塩酸 $3 \mathrm{~mL}$ とイソアミ ルアルコール $27 \mathrm{~mL}$ の混液に溶解したもの） $0.5 \mathrm{~mL}$ を 加えて混和し, 室温で 15 分間放置した後, $530 \mathrm{~nm}$ の 吸光度を測定した。検量線はグルコサミン水溶液（0〜 $60 \mu \mathrm{g} / \mathrm{mL}$ ) を濾液と同様に反応させて作製した。

分析化学的手法に用いた腸の直近部位の組織をカルノ ア液で 24 時間固定した後, $99.5 \%$ エタノールで脱水し た。この後常法によりパラフィン包埋し, $4 \mu \mathrm{m}$ の薄切 標本を 1 尾あたり 1 枚作製して Periodic acid-Schiff-Alcian blue (PAS-AB) pH 2.5 により, 粘液染色した。こ の切片中の粘膜面積あたりの粘液部面積を以下の手法に より測定した。まず粘膜面積は木原ら ${ }^{9)}$ の形態定量法を 用いて測定した。すなわち, 光学顕微鏡で撮影した腸横 断切片像（×40）をコンピュータに取り込み, ランダ ムに放射状の線を書いたシートを組織切片像に重ね, 腸 横断面の中心と考えられる点に, 放射状の線の中心を合 わせた。線と腸が重なっている部分 20 か所について, 腸の中心から䋐毛先端までの距離（a), 絨毛基底までの 距離（ab）を測定し, 画像上のスケールバーを基準と して実際の長さに変換し, 平均した。aを半径とする管 腔部面積 $(\mathrm{Sa})$ と ab を半径とする管腔部＋粘膜層部面 積（Sab）を計算し，Sabから Sa を差し引いて粘膜層 面積を算出した (Fig. 1)。10) つぎに粘液面積は, 組織切

* Tel : 81-11-571-5111. Fax : 81-11-571-7879. Email : kihara@tspirit.tokai-u.jp 


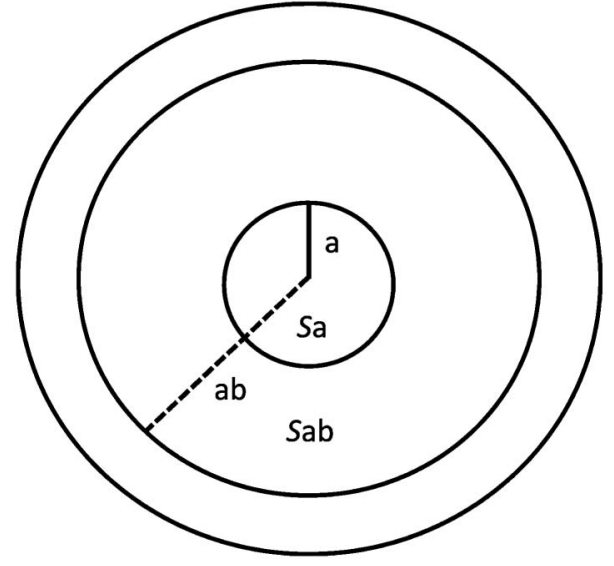

Fig. 1 Schematic drawing of morphometric estimation for mucosal layer area. Distance from approximate center of lumen to villus tip (a) and to basal portion of mucosal layer $(\mathrm{ab})$ were used for the area calculation of circle of radius a $(\mathrm{Sa})$ and circle of radius ab $(\mathrm{Sab})$, respectively. See text for details.

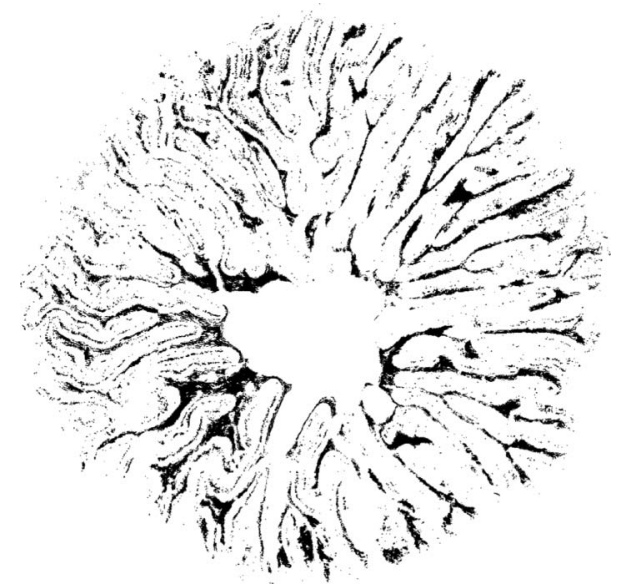

Fig. 2 Cross-section of the gut of grouper by pictureprocessing. Dark area shows PAS-AB-stained mucus area.

片像を画像処理ソフト Photoshop (Adobe Systems Incorporated，CA）上で，無作為に選んだ組織切片像中の PAS-AB 濃染色部分が黒く残るよう二階調化する境界 の閾値を決めた。この閾值をもとに，すべての組織切片 像を二階調化した（Fig. 2)。この画像を画像処理ソフ 卜 ImageJ (National Institutes of Health, MD) に転送 し，黒く残した部分を粘液面積として測定した。以上の 值から粘膜層面積あたりの粘液面積を算出した。

マハ夕腸湿重量 $1 \mathrm{~g}$ あたりのへキソサミン量は, 給䬣 群では $2.04 \pm 0.20 \mathrm{mg}$ ，絶食群では $2.26 \pm 0.16 \mathrm{mg}$ （い ずれも平均值士標準偏差， $n=4)$ であり，一元配置分 散分析の結果, 両群間に有意な差異はなかった。そこ で，給䬬群打よび絶食群のすべての個体データを用い,

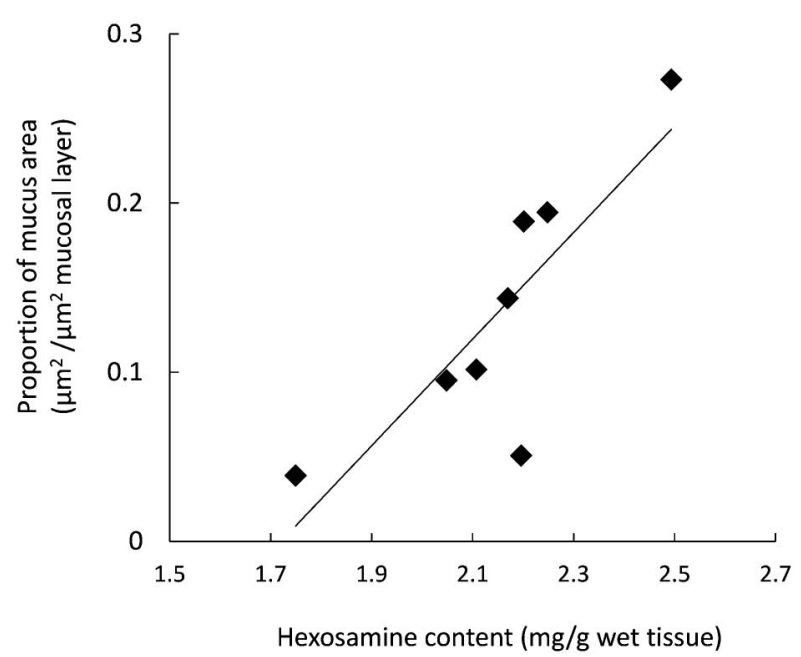

Fig. 3 Correlation between the tissue hexosamine content and the proportion of mucus area from the gut of grouper. A significant positive correlation was confirmed by Spearman's correlation analysis $(n=8, r=$ $0.857, p<0.05)$.

腸湿重量 $1 \mathrm{~g}$ あたりのヘキソサミン量と, 粘膜層 $1 \mu \mathrm{m}^{2}$ あたりの粘液面積をSpearmanの相関分析により検定し た結果，有意に強い正の相関がみられた（Fig. 3)。こ の結果から，本実験の腸管組織中へキソサミン量は組織 中の粘液量を反映していることが強く示唆された。よっ て，本方法は簡便な粘液定量方法として利用可能だと考 えられた。

魚類の粘液はストレス時にも変化することが知られて 抢り，たとえば，過密飼育により生筫内に蓄積する硝酸 が，粘液分泌の昂進を引き起こす。3) 石川（2010）は， ストレスの指標として粘液産生細胞数の測定を行ってお り,11) ニジマス高過密飼育時には, 有意に腸組織内の粘 液産生細胞数が増加することが明らかとなっている。こ れらのことから, 本研究の方法を使って腸管組織粘液量 を定量することで，ストレスをモニターすることも可能 ではないかと考えられる。

本方法は，含まれる粘液の量にもよるが乾燥重量 1 $\mathrm{mg}$ 程度の微量試料でも測定ができること, ${ }^{8)}$ 組織切片 の作製に比べ，短時間に多数のサンプルを処理すること ができること, 養殖現場などでも実施可能なことから, 魚類組織内粘液の有用な評価法だと考えられた。今後 は，養殖魚のストレス検出法，および皮膚粘液の定量へ の応用などについても検討をすすめたい。

\section{文献}

1）廣瀬一美，間野伸宏. 魚類の皮膚生体防御機構. 月刊 海 洋/号外 1988; 4: 131.

2）渡辺 翼. 魚類の免疫学. 恒星社厚生閣 2003: 62.

3) 小川和夫, 室賀清邦. 改訂 - 魚病学概論. 恒星社厚生閣 2008: 11-12. 
4）加藤卓次, 郡大裕, 鈴木邦夫, 多田利男, 野村元積, 伊 藤重二, 佐藤富貴子, 藤木典生. 病院健常者ならびに胃 潰瘍患者における胃粘膜内へキソサミンの定量. 日本消 化器病学会雑誌 1988; 85: 1051-1059.

5) Oketani K, Murakami M, Fujisaki H, Fujisaki H, Wakabayashi T, Hotta K. Effect of geranylgeranylacetone on aspirin-induced changes in gastric glycoproteins. Jpn J Pharmacol. 1983; 33: 593-601.

6）知名真智子．ヤイトハタの粘液胞子虫性やせ病．養殖 2010; 9: 94.

7) Neuhaus OW, Letzring M. Determination of hexosamines in tissues. Anal. Chem. 1957; 29: 1230-1233.

8）桶谷 清, 村上学, 藤崎秀明, 若林康夫, 鶴井光治, 勝 亦重弘, 花城清史, 原田容治, 萩原奉祐. ヘキソサミン を指標とした粘液糖蛋白質の簡易比色定量法一消化管粘
膜からの生検試料に関して. 医学のあゆみ 1984; 131: $745-749$.

9) Kihara M, Ohba K, Sakata T. Trophic effect of dietary lactosucrose on intestinal tunica muscularis and utilization of this sugar by gut microbes in red seabream Pagrus major, a marine carnivorous teleost, under artificial rearing. Comp. Biochem. Physiol. 1995; 112A: 629-634.

10) Kihara M, Sakata T. Fermentation of Dietary Carbohydrates to Short-Chain Fatty Acid by Gut Microbes and its Influence on Intestinal Morphology of a Detritivorous Teleost Tilapia (Oreochromis niloticus). Comp. Biochem. Physiol. 1997; 118A: 1201-1207.

11）石川孝典, サケ科魚類へのアスコルビン酸最適投与法確 立実験. 栃木県水産試験場研究報告第 53 号 (平成 20 年 度） $2010 ; 52-59$. 